\title{
Australian Journal of Crop Science \\ Productivity and quality of soybean seeds of determinate and indeterminate growth types desiccated in pre-harvest
}

\author{
André Ricardo Gomes Bezerra ${ }^{*}$, Tuneo Sediyama ${ }^{1}$, Cosme Damião $\mathrm{Cruz}^{2}$, Francisco Charles dos \\ Santos Silva ${ }^{1}$, Amilton Ferreira da Silva ${ }^{1}$, Daniele Piano Rosa ${ }^{1}$, Luiz Antônio dos Santos Dias ${ }^{1}$
}

\author{
${ }^{1}$ Department of Plant Science, Federal University of Viçosa, 36570-000, Viçosa-MG, Brazil \\ ${ }^{2}$ Department of Biology, Federal University of Viçosa, 36570-000, Viçosa-MG, Brazil
}

*Corresponding author: bezerra.agro@yahoo.com.br

\begin{abstract}
Desiccation aims to control weeds and cause crop defoliation. The procedure facilitates the work of harvesters, allows earlier harvesting and standardization, and can reduce losses. The objective of this study was to evaluate the effect of pre-harvest desiccation on cycle time, seed yield and seed physiological quality of soybean cultivars of determinate and indeterminate growth types. The determinate and indeterminate cultivars 'BRS Valiosa' RR and 'MSoy 7211' RR were used for experiment. Three desiccation stages: R5.7, R6.5, R7.3 and a control treatment (R8) were tested in a $2 \times 4$ factorial scheme, with four replications. The cycle, seed water content, yield $\left(\mathrm{kg} \mathrm{ha}^{-1}\right), 100$-seed weight, protein content, proportion of seeds per sieve (6.0, 5.5, 5.0 and 4.0mm); greenish, defective and normal seed percentages; and the physiological qualities of the seeds were evaluated. There was interaction between cultivar and desiccation stage for 100-seed weight, seed oil content and germination. In relation to the main factors, cultivars and stage of desiccation, only the $5.5 \mathrm{~mm}$ sieve fraction was not significant. Early desiccation at the R5.7 and R6.5 stages reduced yield by up to $27 \%$. It was possible to advance the harvest of 'MSoy 7211 ' by up to 11 days without yield loss. Germination, however, was not affected by stage of desiccation. Desiccation at the R7.3 stage did not reduce the yield, strength or germination in either cultivar.
\end{abstract}

Keywords: desiccant; germination; Glycine max; maturity; seed physiological quality.

Abbreviations: INMET_National Institute of Meteorology, NMR_ Nuclear magnetic resonance, IVE_Index of emergence speed, ANOVA_Analyses of variance, PSI_Photosystem I.

\section{Introduction}

Soybeans must be harvested soon after they reach the R8 stage, in order to avoid losses quality due to exposure to weather, microorganisms and insects (Toledo et al., 2009). In ideal conditions, the harvest should be performed at physiological maturity. However, the seeds generally reach physiological maturity at moisture levels higher than $30 \%$, making their mechanical harvesting unfeasible (Marcos Filho, 2005; Carvalho and Nakagawa, 2012). One way to accelerate water loss is the adoption of chemical products (desiccants) to promote artificial drying of the plants. Paraquat, for example, blocks photosynthesis by accepting electrons from photosystem I (PSI), acting in the reducing end of PSI and inhibiting the reduction of ferredoxin, resulting in depletion of NADPH and the inhibition of $\mathrm{CO}_{2}$ fixation. The increased efficiency of electron capture by Paraquat will enhance the linear electron transport rate and the Paraquat radicals thus formed will transfer electrons to molecular oxygen to produce superoxide radicals, causing the formation of reactive oxygen species (Moustaka and Moustakas, 2014). Desiccation also aims to control weeds and cause crop defoliation. The procedure facilitates the work of harvesters, allows earlier harvesting and standardization, and can reduce losses. Furthermore, it improves the seed quality, reducing losses due to pests and fungi that affect the crop at the end of its cycle (Toledo et al., 2009). This practice is not new in the production system; it was previously studied for several years by Rahman et al. (2004), for example. Recently, the study of pre-harvest desiccation has resumed as some issues still require resolution, especially concerning the appropriate desiccation time (Kappes et al., 2008; Griffin et al., 2010; Boudreaux and Griffing (2011); Malaspina et al., 2012) and the influence of the growth type of the cultivar (Inoue et al., 2003). For the producer, choosing the right time to desiccate is the most difficult decision, because the maintenance of physiological quality and especially the yield must be considered of paramount importance. Some works have shown that the earlier the desiccation the greater the losses in seed weight (Kappes et al., 2008; Lamego et al., 2013). Kappes et al. (2008) reported reductions of 17.5, 39 and $44 \%$ respectively, when desiccation was performed at the R7.2, R7.1 and R6.0 stages. Moreover, desiccation at R7.3 did not result in a decrease in crop yield. However, there is little information about desiccation time taking the plant growth type into account. Maturation in plants of indeterminate growth type occurs predominantly from the base to the apex of the plant, while plants of determinate type mature from apex to base. According to Inoue et al. (2003), the most suitable stage for drying soybeans of indeterminate growth type is R7.5. However, in practice it appears that under these conditions there is little to be gained from early harvesting.

Advancing the soybean harvest by desiccation offers advantages for farmers, especially for those who wish to cultivate off-season following soybean culture. Therefore, depending on the situation, desiccation can offer significant cost benefits. In regions where the climate during the R6.0 and R7.0 stages is characterized by sparse rainfall and high temperatures, the application of desiccants is not advised, 
unless it is justified by, for example, the presence of weeds that hinder the harvesting and leaf retention (Lacerda et al., 2001).

Thus, the present study was aimed at evaluating the effect of pre-harvest desiccation of soybean cultivars of determinate and indeterminate growth types on the cycle time, yield, oil and protein content, and physiological seed quality.

\section{Results}

There were significant differences $(\mathrm{p} \leq 0.05)$ between cultivars and desiccation stages and interactions between them for the cycle time and 100-seed weight characteristics. For seed yield, only an effect of desiccation stage was found (Table 1). The cycle lasted on average 115 days for 'MSoy 7211' and 132 days for 'BRS Valiosa'. 'MSoy 7211' is considered an early maturing (102 to 108 days) cultivar, while the 'BRS Valiosa' cultivar is semi-late (126 to 145 days) in Minas Gerais (Tecnologias, 2011). In 'MSoy 7211', desiccation decreased the normal cycle time, while in 'BRS Valiosa' desiccation at R5.7 and R6.5 resulted in cycles equal times (128 days), which in turn differed from the 136 day cycle time with desiccation at R7.3 or R8.0. Desiccation at stage R6.5 promoted reduction of the cycle time by 17 and 8 days for 'MSoy 7211' and 'BRS Valiosa', respectively (Table 1). The harvest was delayed after desiccation of 'BRS Valiosa' at the R5.7 stage due to precipitation after the treatment. Thus, the seeds remained in the field exposed to weather conditions and microorganisms for a longer time. In 'BRS Valiosa' desiccation at R7.3 did not advance the cycle, which was completed in 136 days, equal to the cycle time in R8 (Control). For the 'MSoy 7211' cultivar, desiccation at the same stage decreased the cycle time by 11 days. It has been observed that the earlier the desiccation the greater its influence on seed yield. With desiccation at stage R5.7, a lower yield average $\left(1,596 \mathrm{~kg} \mathrm{ha}^{-1}\right)$ was obtained. However, the higher yield $\left(2,204 \mathrm{~kg} \mathrm{ha}^{-1}\right)$ verified in the control did not differ from the yield obtained with desiccation at stage R7.3 (Table 1).

The 100-seed weight differed $(\mathrm{p} \leq 0.05)$ between cultivars when desiccation was performed at R5.7 or R6.5. On the other hand, no difference was found between desiccation at R7.3 and harvest at R8 (Table 1). 'BRS Valiosa' had the highest 100-seed weight in all treatments, except when desiccation was performed at R7.3, when 'MSoy 7211' was superior. The 'BRS Valiosa' desiccation at R7.3 coincided with the occurrence of daily precipitation and high temperatures, which probably favored higher seed respiration, resulting in greater degradation of their reserves. For 'BRS Valiosa', the 100-seed weight did not differ in any of the studied treatments, whereas for 'MSoy 7211', there was no difference in 100-seed weight between desiccation at R7.3 and R8 but those weights were significantly different compared with desiccation at R6.5 and R5.7. The 100-seed weight increased when the plants were desiccated later, likely because of the gradual accumulation of dry matter in seeds. Desiccation caused an average reduction in the 100-seed weight of 28, 17 and $11 \%$ at the R5.7, R6.5 and R7.3 stages, respectively. Interaction between desiccation stage and cultivar was observed for seed oil content. Oil content in seeds of 'MSoy 7211' increased as desiccation stage became nearer to R8, whereas the seed oil content in R7.3 did not differ from the control (R8) (Table 1). For 'BRS Valiosa' the maximum oil content was obtained by desiccation at R7.3, outperforming harvest at R8. Desiccation at R5.7 reduced the seed oil content by $8 \%$ and $2 \%$ for 'MSoy 7211 ' and 'BRS
Valiosa', respectively. Seed protein content was greatest in plants desiccated at stage R5.7, followed by non-desiccated plants (Table 1). 'MSoy 7211' had a higher mean protein content than 'BRS Valiosa'.

Regarding seed water content, a significant difference among cultivars (Table 1) was found, where the average for 'MSoy 7211' (13.94\%) exceeded that for 'BRS Valiosa' $(12.88 \%)$. These water contents are within the acceptable level for mechanical harvesting and preservation of postharvest seed quality. In the classification of seeds by size, there was an interaction between desiccation time and cultivar affecting the proportion of seeds in the $6.0 \mathrm{~mm}$ fraction. For the $5.5 \mathrm{~mm} 5.0 \mathrm{~mm}$ and $4.0 \mathrm{~mm}$ fractions there was no difference (Table 2). In the $6.0 \mathrm{~mm}$ fraction the superiority of 'BRS Valiosa' was confirmed. Early desiccation reduced the percentage of seeds of $6.0 \mathrm{~mm}$ size from $18.16 \%$ in the control treatment to less than $5 \%$ with R5.7 treatment (Table 3). In the $5.0 \mathrm{~mm}$ sieve fraction the highest average was found with desiccation at R6.5, differing from the other treatments.

The percentage of greenish seeds was found to be greater in 'BRS Valiosa'. Regarding the desiccation stage, the percentage of greenish seeds decreased with the proximity to physiological maturity (Table 3). The percentage of defective seeds showed results similar to those for greenish seeds in relation to desiccation time. However, no differences between cultivars were found. Time of desiccation did not influence the percentage of normal seeds. Of the cultivars, 'MSoy 7211' had the highest average percentage of normal seeds (Table 3).

In the physiological quality assessment, significant interactions $(\mathrm{p} \leq 0.05)$ were found between cultivars and desiccation stage for first count, germination, seedling length, root length and accelerated aging. For root dry matter there was no effect of desiccation stage or cultivar $(\mathrm{p} \leq 0.05)$ and there was no effect of cultivar $(\mathrm{p} \leq 0.05)$ on seedling dry matter. There was no significant difference $(p \leq 0.05)$ in variation of sand emergence and emergence speed rates. The highest values obtained for the first count were with desiccation at R5.7 and R8.0 for 'MSoy 7211' and 'BRS Valiosa', respectively (Table 4). On the other hand, the lowest values for the first count were different between the two cultivars. In 'MSoy 7211', the R7.3 desiccation stage differed from the others, with a very low value. During desiccation at the R7.3 stage, there was constant daily rainfall that delayed the seed harvest, leaving the plants in the field, exposed to weather and microorganisms for a longer period.

Regarding the cultivar effect on germination, a significant difference $(p \leq 0.05)$ was observed only with desiccation at the R5.7 stage, when the highest germination percentage was obtained with the 'MSoy 7211' cultivar (Table 4). Among the different desiccation stages, the lowest germination percentage was observed in seeds derived from desiccation at R7.3, due to the same factors as for the first count. Seedlings of 'BRS Valiosa' were longer, except in the control (R8.0). There was no difference in seedling length between the different desiccation time groups for 'BRS Valiosa'. Thus, regardless of the stage when desiccation was performed, there was no effect of the herbicide paraquat on seedling length (Table 4).

The root length of seedlings grown from seeds from plants desiccated in R6.5 and R8.0 differed among cultivars, with 'MSoy 7211' highest than 'BRS Valiosa' (Table 4). Generally, seedlings from seeds collected in R8.0 had a longer root system, except for the R7.3 stage derived seedlings. Plants desiccated in R7.3 had their harvest delayed 
Table 1. Averages on cycle time, seed yield, 100-seeds weight, oil content, protein and water content of two soybean cultivars desiccated at different seasons with Paraquat. ${ }^{1}$

\begin{tabular}{|c|c|c|c|c|c|c|}
\hline \multirow{2}{*}{ Evaluation } & \multirow{2}{*}{ Cultivar } & \multicolumn{4}{|c|}{ Desiccation time } & \multirow{2}{*}{ Mean } \\
\hline & & R5.7 & R6.5 & R7.3 & $\mathrm{R} 8.0$ & \\
\hline \multirow{3}{*}{ Cycle (days) } & MSoy 7211 & $105 \mathrm{Bc}$ & $106 \mathrm{Bc}$ & $112 \mathrm{Bb}$ & $123 \mathrm{Ba}$ & 115 \\
\hline & BRS Valiosa & $128 \mathrm{Ab}$ & $128 \mathrm{Ab}$ & $136 \mathrm{Aa}$ & $136 \mathrm{Aa}$ & 132 \\
\hline & Mean & $116,5 \mathrm{c}$ & $117 \mathrm{c}$ & $124 \mathrm{~b}$ & $129,5 \mathrm{a}$ & $2.39^{2}$ \\
\hline \multirow{3}{*}{ Seed yield $\left(\mathrm{kg} \mathrm{ha}^{-1}\right)$} & MSoy 7211 & 1,624 & 1,841 & 2,350 & 2,231 & 2,011 \\
\hline & BRS Valiosa & 1,569 & 1,660 & 1,789 & 2,177 & 1,799 \\
\hline & Mean & $1,596 \mathrm{c}$ & $1,750 \mathrm{bc}$ & $2,070 \mathrm{ba}$ & $2204 \mathrm{a}$ & $419.64^{2}$ \\
\hline \multirow{3}{*}{$\begin{array}{l}\text { 100-seeds } \\
\text { Weight (g) }\end{array}$} & MSoy 7211 & $11.17 \mathrm{Bb}$ & $12.52 \mathrm{Bb}$ & $16.37 \mathrm{Aa}$ & $16.88 \mathrm{Aa}$ & 14.23 \\
\hline & BRS Valiosa & $14.03 \mathrm{Ab}$ & $16.51 \mathrm{Aab}$ & $14.74 \mathrm{Ab}$ & $18.21 \mathrm{Aa}$ & 15.87 \\
\hline & Mean & $12,60 \mathrm{c}$ & $14,51 \mathrm{bc}$ & $15,56 \mathrm{ab}$ & $17,55 \mathrm{a}$ & $2.26^{2}$ \\
\hline \multirow{3}{*}{ Oil (\%) } & MSoy 7211 & $21.27 \mathrm{Bc}$ & $22.47 \mathrm{Ab}$ & $23.13 \mathrm{Aa}$ & $23.13 \mathrm{Aa}$ & 22.50 \\
\hline & BRS Valiosa & $21.93 \mathrm{Ab}$ & $22.08 \mathrm{Bb}$ & $22.82 \mathrm{Aa}$ & $22.28 \mathrm{Ab}$ & 22.28 \\
\hline & Mean & $21.60 \mathrm{c}$ & $22.28 \mathrm{~b}$ & $22.98 \mathrm{a}$ & $22.71 \mathrm{ab}$ & $0.556^{2}$ \\
\hline \multirow{3}{*}{ Protein $(\%)$} & MSoy 7211 & 42.41 & 42.02 & 42.09 & 41.92 & $42.11 \mathrm{~A}$ \\
\hline & BRS Valiosa & 41.56 & 39.11 & 39.92 & 40.83 & $40.36 \mathrm{~B}$ \\
\hline & Mean & $41.98 \mathrm{a}$ & $40.56 \mathrm{~b}$ & $41.00 \mathrm{ab}$ & $41.38 \mathrm{ab}$ & $1.11^{2}$ \\
\hline \multirow{3}{*}{ Water content $(\%)$} & MSoy 7211 & 14.32 & 13.97 & 13.95 & 13.53 & $13.94 \mathrm{~A}$ \\
\hline & BRS Valiosa & 13.74 & 11.24 & 13.94 & 12.58 & $12.88 \mathrm{~B}$ \\
\hline & Mean & 14.03 & 12.61 & 13.95 & 13.06 & $2.01^{2}$ \\
\hline
\end{tabular}

${ }^{1}$ Means followed by the same lowercase letter in the line and uppercase letter in column do not differ between themselves by Tukey's test $(\mathrm{p} \leq 0.05)$ and $\mathrm{F}$ test $(\mathrm{p} \leq 0.05)$, respectively. ${ }^{2}$ Value refers to least significant difference (LSD) for means of desiccation time.

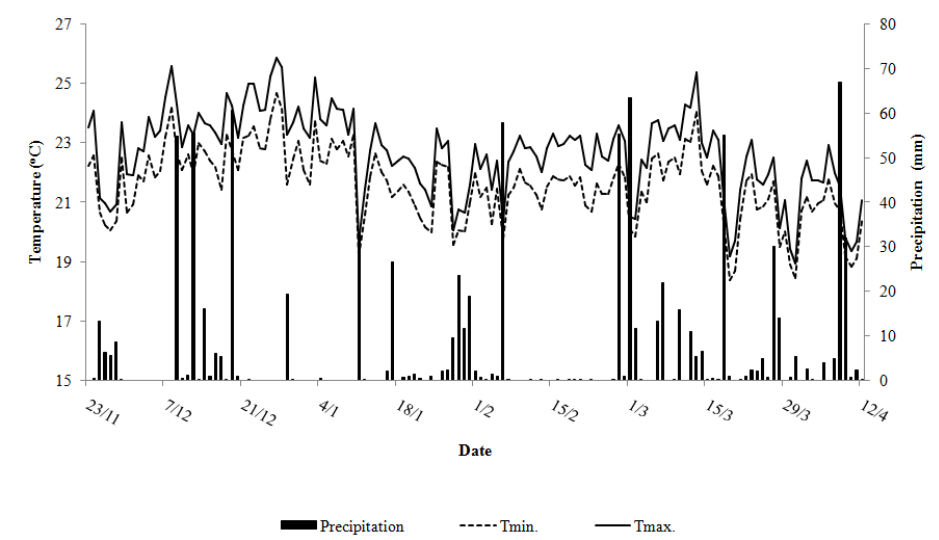

Fig 1. Daily data of maximum and minimum air temperature and precipitations during the conduct of experiment.

due to excessive moisture caused by continuous rains and mild temperatures. Excess of rain during the pre-harvest period, besides speeding up the metabolism, promotes the incidence of microorganisms, affecting the seed physiological potential. For 'BRS Valiosa' there was no difference in root lenght between desiccation times. In contrast, the root length of seedlings from 'MSoy 7211' differed depending on the desiccation time. However, the type of paraquat product used did not affect root lenght, unlike glyphosate (Daltro et al., 2010, Toledo et al., 2012). 'MSoy 7211' had higher average seedling dry matter, about $7 \%$ greater than 'BRS Valiosa' (Table 4). There was no difference in dry matter between seedlings grown from seeds from plants desiccated at different stages. As for the root dry matter, a difference was found only between cultivars, also with 'MSoy 7211' being superior.

The late harvest of 'MSoy 7211' in R7.3 caused a reduction in seed germination after accelerated aging (Table 5). A similar result was obtained in the germination test in paper rolls. A difference between cultivars was observed only with R5.7 stage desiccation where 'MSoy 7211' was superior; and with R7.3 stage desiccation, where the seeds of 'BRS Valiosa' had a higher germination percentage. When the plants were prematurely desiccated (R5.7), germination of the seeds of 'BRS Valiosa' was seriously affected after accelerated aging. For the same cultivar, there was no difference between the means of the three other stages.

Seeds from plants desiccated at the R6.5 and R7.3 stages, for both 'MSoy 7211' and 'BRS Valiosa', were more vigorous than those from the other treatments. However, they did not differ from those plants collected in R8. Most likely, these desiccations were performed at stages near to the physiological maturity point of each cultivar, at which time the seeds have maximum physiological quality (Marcos Filho, 2005; Carvalho and Nakagawa, 2012). The sand emergence and emergence speed index was not affected by desiccation (Table 5).

\section{Discussion}

As the desiccation time of the crop approached the R8.0 stage, a smaller reduction in the normal cycle time for the cultivar was verified, corroborating Guimarães et al. (2012). Crop cycle anticipation depends on the desiccation stage, so choosing the right moment is an important step in the process. Therefore, it is extremely important that the soybean producer knows the stages of plant development. The seed yield results are in accordance with Lamego et al. (2013) who reported that desiccation without loss of production occurred only with desiccation at the R7.3 stage. Desiccant application 
Table 2. Percentage of seeds by size of two soybeans cultivars desiccated in different seasons with Paraquat. ${ }^{1}$

\begin{tabular}{|c|c|c|c|c|c|c|}
\hline \multirow{2}{*}{ Evaluation } & \multirow{2}{*}{ Cultivar } & \multicolumn{4}{|c|}{ Desiccation time } & \multirow{2}{*}{ Mean } \\
\hline & & R5.7 & R6.5 & R7.3 & R8.0 & \\
\hline \multirow{3}{*}{$6.0(\mathrm{~mm})$} & MSoy 7211 & 1.28 & 1.93 & 5.09 & 16.4 & $6.17 \mathrm{~B}$ \\
\hline & BRS Valiosa & 8.56 & 11.66 & 13.38 & 19.92 & $13.38 \mathrm{~A}$ \\
\hline & Mean & $4.92 \mathrm{~b}$ & $6.79 \mathrm{~b}$ & $9.23 \mathrm{~b}$ & $18.16 \mathrm{a}$ & $8.83^{2}$ \\
\hline \multirow{3}{*}{$5.5(\mathrm{~mm})$} & MSoy 7211 & 28.27 & 18.86 & 43.79 & 40.91 & $32.92 \mathrm{~A}$ \\
\hline & BRS Valiosa & 18.89 & 25.08 & 30.60 & 33.60 & $27.04 \mathrm{~A}$ \\
\hline & Mean & 23.58 & 21.97 & 37.19 & 37.25 & $22.97^{2}$ \\
\hline \multirow{3}{*}{$5.0(\mathrm{~mm})$} & MSoy 7211 & 67.99 & 77.83 & 49.70 & 41.12 & $59.16 \mathrm{~A}$ \\
\hline & BRS Valiosa & 69.24 & 62.75 & 53.26 & 44.18 & $57.36 \mathrm{~A}$ \\
\hline & Mean & $68.61 \mathrm{ab}$ & $70.29 \mathrm{a}$ & $51.48 \mathrm{ab}$ & $42.65 \mathrm{~b}$ & $27.27^{2}$ \\
\hline \multirow{3}{*}{$4.0(\mathrm{~mm})$} & MSoy 7211 & 2.26 & 1.09 & 0.73 & 0.67 & $1.19 \mathrm{~A}$ \\
\hline & BRS Valiosa & 2.19 & 1.64 & 0.75 & 0.73 & $1.33 \mathrm{~A}$ \\
\hline & Mean & $2.22 \mathrm{a}$ & $1.36 \mathrm{ab}$ & $0.74 \mathrm{~b}$ & $0.7 \mathrm{~b}$ & $0.997^{2}$ \\
\hline
\end{tabular}

Table 3. Percentage of greenish, defective and normal seeds for two soybeans cultivars desiccated at different times with Paraquat.

\begin{tabular}{|c|c|c|c|c|c|c|}
\hline \multirow{2}{*}{ Evaluation } & \multirow{2}{*}{ Cultivar } & \multicolumn{4}{|c|}{ Desiccation time } & \multirow{2}{*}{ Mean } \\
\hline & & R5.7 & R6.5 & R7.3 & $\mathrm{R} 8.0$ & \\
\hline \multirow{3}{*}{ Greenish seeds } & MSoy 7211 & 1.84 & 2.46 & 1.53 & 0.19 & $1.51 \mathrm{~B}$ \\
\hline & BRS Valiosa & 8.72 & 6.72 & 5.93 & 1.62 & $5.75 \mathrm{~A}$ \\
\hline & Mean & $5.28 \mathrm{a}$ & $4.59 \mathrm{a}$ & $3.73 \mathrm{ab}$ & $0.91 \mathrm{~b}$ & $3.39^{2}$ \\
\hline \multirow{3}{*}{ Defective seeds } & MSoy 7211 & 13.43 & 9.15 & 4.87 & 6.00 & $8.36 \mathrm{~A}$ \\
\hline & BRS Valiosa & 7.56 & 9.25 & 5.56 & 7.06 & $7.86 \mathrm{~A}$ \\
\hline & Mean & $10.49 \mathrm{a}$ & $9.2 \mathrm{ab}$ & $5.21 \mathrm{~b}$ & $6.53 \mathrm{ab}$ & $4.94^{2}$ \\
\hline \multirow{3}{*}{ Normal seeds } & MSoy 7211 & 84.72 & 88.37 & 93.59 & 93.03 & $89.93 \mathrm{~A}$ \\
\hline & BRS Valiosa & 83.72 & 84.06 & 88.50 & 91.31 & $86.89 \mathrm{~B}$ \\
\hline & Mean & 84.22 b & $86.21 \mathrm{ab}$ & $91.04 \mathrm{a}$ & $92.17 \mathrm{a}$ & $6.07^{2}$ \\
\hline
\end{tabular}

Means followed by the same lowercase letter in the line and uppercase letter in column do not differ between themselves by Tukey's test ( $\mathrm{p} \leq 0.05)$ and $\mathrm{F}$ test ( $\mathrm{p} \leq 0.05)$, respectively. ${ }^{2}$ Value refers to least significant difference (LSD) for means of desiccation time.

Table 4. Average of first count, germination, length and dry matter of aerial parts and root from seeds of two soybean cultivars desiccated at different times with Paraquat. ${ }^{1}$

\begin{tabular}{lcccccc}
\hline \multirow{2}{*}{ Evaluation } & \multirow{2}{*}{ Cultivar } & \multicolumn{4}{c}{ Desiccation time } & \multirow{2}{*}{ Mean } \\
\cline { 3 - 6 } & & R5.7 & R6.5 & R7.3 & R8.0 & \\
\hline \multirow{2}{*}{ First count $(\%)^{3}$} & MSoy 7211 & 88.00 & 79.50 & 56.50 & 82.00 & 76.50 \\
& BRS Valiosa & 80.50 & 84.00 & 72.00 & 86.00 & 80.60 \\
& Mean & $84.25 \mathrm{a}$ & $81.75 \mathrm{a}$ & $64.25 \mathrm{~b}$ & $84.00 \mathrm{a}$ & $0.122^{2}$ \\
\hline \multirow{3}{*}{ Germination (\%) } & MSoy 7211 & $95.50 \mathrm{Aa}$ & $86.50 \mathrm{Aa}$ & $73.50 \mathrm{Ab}$ & $86.00 \mathrm{Aa}$ & 85.40 \\
& BRS Valiosa & $84.00 \mathrm{Bab}$ & $90.00 \mathrm{Aa}$ & $77.50 \mathrm{Ab}$ & $89.00 \mathrm{Aa}$ & 85.10 \\
& Mean & $89.70 \mathrm{a}$ & $88.30 \mathrm{a}$ & $75.50 \mathrm{~b}$ & $87.50 \mathrm{a}$ & $8.30^{2}$ \\
\hline \multirow{3}{*}{ Seedling length $\left(\mathrm{cm} \mathrm{plant}^{-1}\right.$ ) } & MSoy 7211 & $10.45 \mathrm{Bab}$ & $11.15 \mathrm{Bab}$ & $8.95 \mathrm{Bb}$ & $13.37 \mathrm{Aa}$ & 10.98 \\
& BRS Valiosa & $14.27 \mathrm{Aa}$ & $14.54 \mathrm{Aa}$ & $11.88 \mathrm{Aa}$ & $11.64 \mathrm{Ba}$ & 13.08 \\
& Mean & $12.40 \mathrm{a}$ & $12.84 \mathrm{ab}$ & $10.40 \mathrm{a}$ & $12.50 \mathrm{ab}$ & $2.31^{2}$ \\
\hline \multirow{3}{*}{ Root length (cm plant ${ }^{-1}$ ) } & MSoy 7211 & $14.70 \mathrm{Acb}$ & $16.42 \mathrm{Ab}$ & $13.09 \mathrm{Ac}$ & $19.92 \mathrm{Aa}$ & $16.03 \mathrm{~A}$ \\
& BRS Valiosa & $14.00 \mathrm{Aa}$ & $13.75 \mathrm{Ba}$ & $13.65 \mathrm{Aa}$ & $14.33 \mathrm{Ba}$ & $13.94 \mathrm{~B}$ \\
& Mean & $14.30 \mathrm{~b}$ & $15.10 \mathrm{ab}$ & $13.40 \mathrm{~b}$ & $17.10 \mathrm{a}$ & $2.12^{2}$ \\
\hline \multirow{3}{*}{ Seedling dry matter $\left(\mathrm{g} \mathrm{plant}^{-1}\right.$ ) } & MSoy 7211 & 0.1074 & 0.1221 & 0.0984 & 0.1113 & $0.1098 \mathrm{~A}$ \\
& BR Valiosa & 0.0971 & 0.1034 & 0.0990 & 0.1100 & $0.1024 \mathrm{~B}$ \\
& Mean & $0.1023 \mathrm{ab}$ & $0.1127 \mathrm{a}$ & $0.0987 \mathrm{~b}$ & $0.1107 \mathrm{a}$ & $0.0114^{2}$ \\
\hline \multirow{3}{*}{ Root dry matter $\left(\mathrm{g} \mathrm{plant}^{-1}\right.$ ) } & MSoy 7211 & 0.0134 & 0.0154 & 0.0153 & 0.0204 & $0.0161 \mathrm{~A}$ \\
& BRS Valiosa & 0.0115 & 0.0141 & 0.0160 & 0.0177 & $0.0148 \mathrm{~B}$ \\
& Mean & 0.0209 & 0.0211 & 0.0199 & 0.0211 & $0.0033^{2}$ \\
\hline
\end{tabular}

${ }^{1}$ Means followed by the same lowercase letter in the line and uppercase letter in column do not differ between themselves by Tukey's test (p $\left.\leq 0.05\right)$ and $\mathrm{F}$ test ( $\mathrm{p} \leq 0.05$ ), respectively. ${ }^{2}$ Value refers to least significant difference (LSD) for means of desiccation time.

${ }^{3}$ Original means, accompanied by letters and least significant difference (LSD), obtained from transformed data in arcsine $\sqrt{\mathrm{x} / 100}$. 
Table 5. Means of accelerating aging, seedlings emergence in sand and emergence speed index of desiccated soybeans at different times with Paraquat. ${ }^{1}$

\begin{tabular}{|c|c|c|c|c|c|c|}
\hline \multirow{2}{*}{ Evaluation } & \multirow{2}{*}{ Cultivar } & \multicolumn{4}{|c|}{ Desiccation time } & \multirow{2}{*}{ Mear } \\
\hline & & R5.7 & R6.5 & R7.3 & R8.0 & \\
\hline \multirow{3}{*}{ Accelerated aging $(\%)$} & MSoy 7211 & $79.00 \mathrm{Aa}$ & $84.50 \mathrm{Aa}$ & $56.00 \mathrm{Bb}$ & $79.50 \mathrm{Aa}$ & 74.70 \\
\hline & BRS Valiosa & $54.50 \mathrm{Bb}$ & $78.00 \mathrm{Aa}$ & $82.00 \mathrm{Aa}$ & $80.50 \mathrm{Aa}$ & 73.70 \\
\hline & Mean & $66.75 \mathrm{~b}$ & $81.25 \mathrm{a}$ & $69.00 \mathrm{~b}$ & $80.00 \mathrm{a}$ & $6.24^{2}$ \\
\hline \multirow{3}{*}{ Seedlings emergence in sand (\%) } & MSoy 7211 & 98.50 & 95.00 & 93.00 & 98.00 & 96.10 \\
\hline & BRS Valiosa & 97.20 & 96.00 & 92.00 & 88.70 & 93.50 \\
\hline & Mean & 97.80 & 95.50 & 92.50 & 93.30 & $5.42^{2}$ \\
\hline \multirow{3}{*}{ Emergence speed index } & MSoy 7211 & 8.60 & 9.00 & 8.50 & 9.20 & 8.80 \\
\hline & BRS Valiosa & 8.90 & 8.70 & 8.10 & 8.30 & 8.50 \\
\hline & Mean & 8.75 & 8.89 & 8.33 & 8.76 & $1.36^{2}$ \\
\hline
\end{tabular}

Means followed by the same lowercase letter in the line and uppercase letter in column do not differ between themselves by Tukey's test ( $\mathrm{p} \leq 0.05$ ) and $\mathrm{F}$ test ( $\mathrm{p} \leq 0.05$ ), respectively. ${ }^{2}$ Value refers to least significant difference (LSD) for means of desiccation time.

time is crucial, because when desiccation is performed before physiological seed maturity, it may result in reduction of the crop yield (Bastidas et al., 1971; Kappes et al., 2008; Guimarães et al., 2012; Lamego et al., 2013). However, if the desiccation is appropriately performed at physiological maturity there will be uniformity in plant maturity and harvest anticipation, with no effect on the productive potential (Lacerda et al., 2001; Inoue et al., 2012; Guimarães et al., 2012). Reductions in seed yield found in this study were $27 \%$ with desiccation at R5.7, 20\% with desiccation at R6.5, and 6\% with desiccation at R7.3, compared to harvest at stage R8 (Table 1). Kappes et al. (2008) found that the desiccation performed with diquat or paraquat at R7.3 did not result in a decrease in the final crop yield. However, when the desiccation was performed at stages R7.2, R7.1 and R6.0, reductions of $751(17.5 \%), 1,689(39 \%)$ and 1,908 (44\%) $\mathrm{kg}$ $\mathrm{ha}^{-1}$ were observed, respectively, considering the average of the results from the two desiccants in relation to the average of desiccation at R7.3. The high seed yield reduction caused by desiccation is due to the action of the herbicide used. Paraquat acts by contact, which results in rapid water loss from the dried plant, similar with other herbicides used as desiccants (Malaspina et al., 2012). Consequently, photoassimilate translocation to seeds is probably disrupted, if they are still at the dry matter accumulation stage at the desiccation time.

In cultivars of indeterminate growth type, maturation of pods starts at the bottom, progressing towards the top of the plant. However, for cultivars of determinate growth type, pod maturation occurs mainly from the top downwards. The soybean plant development scale was initially developed for cultivars of indeterminate growth type (Hanway and Thompson, 1967), and a few years later Fehr and Cavinnes (1977) adapted it to cultivars of determinate growth type. However, the modifications made by these authors do not correspond equally with the growth pattern of the two types of plants. The ideal moment for desiccation of determined and indeterminate growth type plants do not coincide at the same developmental stage. It is well known that in plants of determinate growth type, the maturation of pods in the lower third is delayed compared with other parts of the plant. Several studies have shown that earlier desiccation results in a greater loss in seed yield (Bastidas et al., 1971; Kappes et al., 2008; Lamego et al. 2013). In a premature desiccation, the seed has not yet reached physiological maturity i.e. it is still at the stage of dry matter accumulation. The premature death of the plant results in disruption of photoassimilate accumulation in seeds (Marcos Filho, 2005). In contrast, some other studies have reported that there is no influence of desiccant application time on seed weight (Guimarães et al., 2012; Malaspina et al., 2012).
The average seed oil content in soybean is around 20\%, ranging from 13 to $28 \%$ (Sediyama et al., 2009). The seed oil content is affected by the interaction of cultivar and sowing season, due to the influence of temperature during seed development. Generally, soybean has higher oil content when cultivated in warmer environments (Barros and Sediyama, 2009). Currently, few studies have evaluated the effects of desiccation on seed oil contents. Durigan et al. (1980) verified that desiccation of cultivars Santa Rosa and IAC-2 did not affect the seed oil content, provided that it was performed at least 75 and 72 days after the beginning of flowering, respectively.

Durigan et al. (1980) reported that desiccation of cultivars Santa Rosa and IAC-2 did not affect the seed protein content. In most cultivars destined for bran production, the average protein content in soybeans is around $40 \%$, ranging from 30 to $53 \%$ (Sediyama et al., 2009). According to Barros and Sediyama (2009), temperature is not associated with seed protein content and is inversely correlated with oil content. The seed size can have a considerable effect on the initial strength of the seedling, since larger seeds have larger amounts of reserve substances for the development of the embryonic axis. A larger amount of reserves increases the probability of success in seedling establishment, because it allows longer survival in unfavorable environmental conditions (Carvalho and Nakagawa, 2012). However, Krzyzanowski et al. (1991), working with identical parameters, did not find differences in the quality of seeds of different sizes. According to these authors, seed classification by size and weight may be a useful strategy for increasing productivity, since the seed size affects germination, plant strength and yield. The results obtained in this study for greenish, defective and normal seeds are in agreement with Kappes et al. (2008) who studied the effect of desiccation at R6.0, R7.1, R7.2 and R7.3 with diquat and paraquat on soybean yield potential.

The occurrence of greenish soybean seeds can vary depending on environmental factors, the occurrence of pests and diseases, or even inappropriate crop management. Another management practice that can result in this problem is pre-harvest desiccation, in cases where the desiccant is applied before physiological maturity, or when its application is performed correctly but there is uneven plant maturation (França-Neto et al., 2012). During the seed maturation period, when the rapid translocation of reserves is still occurring and the photosynthesis rate is lowest, premature death of the plant prevents the complete degradation of chlorophyll, which results in the production of greenish and low quality seed (Marcos Filho, 2005). Toledo et al. (2012) verified that delay in harvesting reduces the germination of seeds produced by soybean plants desiccated with glyphosate 
in pre-harvest. According to Carvalho and Nakagawa (2012) seeds have maximum strength at the physiological maturity point (stage R7.0) and from that stage onwards the value decreases as a function of the environmental and microbiological conditions to which the seeds are submitted. Desiccation at R5.7 should be performed only when it is desirable to collect seeds with high strength, although this study demonstrates that desiccation at this time results in yield loss. However, Lacerda et al. (2003) reported that soybean seeds derived from plants desiccated at R6.0 every five days did not show the necessary physiological and sanitary potential for marketing.

Kappes et al. (2009) verified that seeds produced by nondesiccated plants showed the highest germination percentage, higher than plants desiccated at the R6.0, R7.1 and R7.2 stages, showing that desiccation at these stages causes damage to seed germination. On the other hand, according to Guimarães et al. (2012), the use of paraquat herbicide promoted better germination and strength in soybean seeds when used at the R6.0 and R7.2 stages, compared with ammonium glufosinate and glyphosate at the same stages. The harvest delay for the plants desiccated at R7.3 seriously decreased seed germination. The values obtained for percentage of seed germination showed that the seeds from this treatment were of low physiological quality as the germination capacity of the seed batch in laboratory conditions must be greater than $80 \%$ - the minimum standard for commercialization.

Daltro et al. (2010) evaluated the effect of four herbicides and two combinations of them on the physiological quality of soybean seeds. They found that only seeds produced from plants desiccated with glyphosate at R6.5 showed a reduction in seedling length. A similar result was also observed by Toledo et al. (2012) who found glyphosate effect on root length, hypocotyl length and total height of the seedlings. Lamego et al. (2013) obtained a higher rate of soybean seedling emergence when seeds were derived from plants desiccated in R6.0. Kappes et al. (2009) verified that soybean seed batches desiccated with Paraquat performed better than controls in seed quality tests. Guimarães et al. (2012) reported that Paraquat herbicide applied in R6.0 and R7.2 stages and glufosinate ammonium herbicide applied at R7.2 provided more vigorous seeds than those from controls. However, Marcandalli et al. (2011) reported that seeds obtained by applying desiccants at the R6.0 stage had lower physiological quality compared with those obtained with the application of desiccant at the R7.0 and R8.0 stages.

\section{Materials and Methods}

\section{Experimental description of site, experimental design, plant material and treatments}

The experiment was carried in Viçosa, Minas Gerais State, Brazil (lat. 20 $46^{\prime} \mathrm{S}$, long. $42^{\circ} 52^{\prime} \mathrm{W}$ and alt. $663 \mathrm{~m}$ ). The climate is Cwa type, according to Köppen's classification, (humid temperate with dry winter). The average annual rainfall is $1,221 \mathrm{~mm}$. Summer is hot and the average temperature in the hottest month is higher than $20^{\circ} \mathrm{C}$. The maximum and minimum temperatures and precipitation were monitored daily during the study period from an automatic weather station at the National Institute of Meteorology INMET, located on the UFV campus (Fig 1).

The soil in the experimental area is classified as RedYellow Ultisol (PVA), clayey. Its chemical composition is as follows: organic matter, $1.97 \mathrm{dag} \mathrm{kg}^{-1} ; \mathrm{pH}\left(\mathrm{H}_{2} \mathrm{O}\right)$, 4.7; $\mathrm{P}$ (Extractor Mehlich 1), $12.2 \mathrm{mg} \mathrm{dm}^{-3} ; \mathrm{K}, \mathrm{Ca}, \mathrm{Mg}$ and $\mathrm{H}+\mathrm{Al}$,

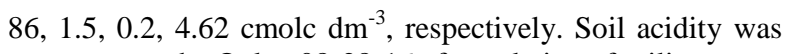
not corrected. Only 08-28-16 formulation fertilizer was applied in the furrows at a dose of $200 \mathrm{~kg} \mathrm{ha}^{-1}$.

The experimental design used randomized blocks with four replicates. The treatments were arranged in a $2 \times 4$ factorial scheme (two cultivars: 'MSoy 7211' RR and 'BRS Valiosa' $\mathrm{RR}$, of determinate and indeterminate growth types, respectively; and three desiccation stages: R5.7, R6.5 and R7.3 and a control, R8). The stages were characterized according to Fehr and Caviness (1977), with minor adaptations: R5.7 - characterized by the presence of seeds in pods with above $85 \%$ filling, in at least one of the four last nodes of the main stem; R6.5 - plants with pods whose seeds are fully developed in at least one of the four nodes on the main stem; R7.3 - plants with $30 \%$ of normal pods having mature coloration on any node of the main stem; and R8 - full maturity, plants with $95 \%$ of pods achieving mature pod color.

The seeds were treated with Derosal ${ }^{\circledR}(30 \mathrm{~g}$ per $100 \mathrm{~kg}$ of seeds) and then inoculated with Bradyrhizobium japonicum ( $400 \mathrm{~g}$ of peat inoculant per $50 \mathrm{~kg}$ of seed). The sowing was performed manually, placing 12 to 15 seeds per meter, in order to obtain a final density of 10 plants per meter. Emergence occurred up to seven days after sowing. Crop management was performed according to the recommendations of Sediyama (2009) and Tecnologias (2010).

The plots consisted of four lines of $3 \mathrm{~m}$, spaced $0.7 \mathrm{~m}$ apart, with an area of $8.4 \mathrm{~m}^{2}$. The two central lines were considered as the useful area, disregarding 0.5 meters at each end. The desiccant herbicide used was Paraquat (Gramoxone 200) at a dose of $2.0 \mathrm{~L} \mathrm{ha}^{-1}$ of the commercial product. The applications were performed in the late afternoon, with a backpack sprayer fitted with a pressure control valve (2.0 Bar or $29 \mathrm{PSI}$ ) and a $0.5 \mathrm{~m}$ bar with two fan type points (model Teejet TTI11002) providing a $1.0 \mathrm{~m}$ wide coverage range and a spray volume of $200 \mathrm{~L} \mathrm{ha}^{-1}$, of which $0.5 \%$ was adjuvant. At the time of spraying, the side parcels received anti-drift protection, consisting of wooden frames and plastic canvas, with an effective height of $2.0 \mathrm{~m}$.

The harvest was performed manually and the plants were threshed in a threshing machine. After harvest the cycle time (that is the number of days from emergency to maturity), seed yield $\left(\mathrm{kg} \mathrm{ha}^{-1}\right)$ corrected to $13 \%$ moisture (wet basis), 100 -seeds weight $(\mathrm{g})$ and other evaluations were reviewed.

\section{Oil content and Protein content}

The oil content was determined by Nuclear Magnetic Resonance (Oxford Instruments). For analysis of oil content by NMR, a sample of $20 \mathrm{~g}$ of seeds, on average, of each treatment was evaluated. Protein content: Using the Kjeldahl (IAL, 1985) method, approximately $0.2 \mathrm{~g}$ of ground seeds per treatment was assayed.

\section{Seed classification by size}

The total amount of each sample after weighing was passed through a series of wire sieves of round cribble, with dimensions of $6.0,5.5,5.0$ and $4.0 \mathrm{~mm}$.

\section{Greenish, defective and normal seeds}

Greenish seeds were estimated by random sampling, computing the number of greenish seeds contained in the sample. Similarly, the number of defective seeds was obtained, according to the rules for the analysis of physical 
purity (Brazil, 2009). The normal seeds was obtained by subtraction of greenish and defective seeds.

\section{Seed water content, germination, first germination count and accelerated aging tests}

In order to determine the physiological seed quality the following procedures for germination and vigor evaluation were performed: Water content: two replicates of 20 seeds were assayed using the electric oven dehydration method without forced ventilation, at $105 \pm 3^{\circ} \mathrm{C}$, for 24 hours (Brazil, 2009). Germination: Germitest paper towel was used as substrate, with four replicates of 50 seeds for each treatment. They were packed in plastic bags, in a germination chamber at $25^{\circ} \mathrm{C}$, for eight days (Brazil, 2009). First germination count: corresponding to the count on the fifth day of the germination test described above, considering only normal seedlings (Brazil, 2009). Accelerated aging tests: four subsamples of 50 seeds were taken from each treatment. The seeds were spread out on aluminum canvas, in mountings inside adapted plastic boxes (Gerbox), as proposed by Marcos Filho et al., (1999). After this period, the seeds were allowed to germinate as described in the germination test, and the counting of the normal seedling number was performed on the fifth day after the test installation.

\section{Seedling length, seedling dry weight, seedling emergence in sand and index of emergence speed}

Seedling length: determined with the use of four replicates of 10 seeds per treatment, arranged on a line drawn lengthwise in the upper third of the paper. The substrates, rolls of germitest paper, were moistened with water of a volume equivalent to 2.5 times the weight of the dry substrate. After seeding the rolls were kept at $25^{\circ} \mathrm{C}$. The evaluation was made on the eighth day after sowing, with the separation of shoots and roots of normal seedlings (Brazil, 2009). Seedling dry weight: determined using the seedlings obtained at the end of the length test. Replicates of each treatment were placed in paper bags and placed in a stove with forced air circulation at $65^{\circ} \mathrm{C}$ for 72 hours. After cooling, each replicate was weighed on scales with an accuracy of $0.01 \mathrm{~g}$ (Nakagawa, 1999). Seedling emergence in sand: four subsamples of 50 seeds per treatment were taken. These were sown at a depth of three centimeters in plastic trays $(42 \times 28 \times 10 \mathrm{~cm}$ in length, width and depth, respectively) containing washed sand. Counting of the emerged seedlings was performed twelve days after sowing, according to Nakagawa (1999). Index of emergence speed: the index of emergence speed was calculated according to Maguire (1962):

$I V E=\frac{N_{1}}{D_{1}}+\frac{N_{2}}{D_{2}} \ldots \frac{N_{n}}{D_{n}}$

Where: $\mathrm{N}_{1}$ is the number of emerged seedlings on the first count, $D_{1}$ is the number of days to the first count, $N_{n}$ is the number of emerged seedlings at last count and $D_{n}$ is number of days for the last count.

\section{Statistical analyses}

Percentage data were tested for normality (Lilliefors). When normality was not observed as in the case of the first count germination, the values were transformed in arcsine $\sqrt{\mathrm{x} / 100}$. Analyses of variance (ANOVA) were performed. The means for the desiccation factor were compared using Tukey's test at $5 \%$ probability, while means related to the cultivar factor were compared using ANOVA $\mathrm{F}$ - tests at 5\% probability. The statistical analysis of data was processed using the GENES program (Cruz, 2013).

\section{Conclusions}

Reduction in soybean seed yield was observed when desiccation was performed at R5.7 and R6.5 phenological stages. Advancing the harvest by up to 11 days in the indeterminate growth type cultivar 'MSoy 7211' reduces yield. However, in the determinate growth type cultivar 'BRS Valiosa', was not possible to advance the harvest without interfering with productivity. The seed oil content decreased more in 'MSoy 7211' than in 'BRS Valiosa' when desiccated at R5.7. Desiccation with Paraquat at R7.3 did not reduce seed yield, strength or germination in either cultivar.

\section{Acknowledgement}

Thanks to Coordenação de Aperfeiçoamento de Pessoal de Nível Superior (Capes) for the fellowships.

\section{References}

Barros HB, Sediyama T (2009) Luz, umidade e temperatura. In: Sediyama T (ed), Tecnologias de produção e usos da soja. Mecenas, Londrina.

Bastidas G, Franco HE, Cruz R (1971) Defoliantes en soya (Glycine $\max$ (L.) Merrill). Acta Agron. 21:51-58.

Boudreaux JM, Griffin JL (2011) Application timing of harvest aid herbicides affects soybean harvest and yield. Weed Technol. 25:38-43.

Brasil - Ministério da Agricultura, Pecuária e Abastecimento (2009) Regras para análise de sementes. MAPA/SDA, Brasília.

Carvalho NM, Nakagawa J (2012) Sementes: ciência, tecnologia e produção, 5th edn. Funep, Jaboticabal.

Cruz CD (2013) GENES - a software package for analysis in experimental statistics and quantitative genetics. Acta Sci Agron. 35:271-276.

Daltro EMF, Albuquerque MCF, França-neto JB, Guimarães SC, Gazziero DLP, Henning AA (2010) Aplicação de dessecantes em pré-colheita: efeito na qualidade fisiológica de sementes de soja. Rev bras Sementes. 32:111-122.

Durigan JC, Durigan JF, Carvalho NM (1980) Aplicação, em pré-colheita, de dessecantes em duas cultivares de soja (Glycine max (L.) Merrill). III - Efeitos sobre a composição química (protéica, óleo e cinzas) e resíduos nas sementes. Planta Daninha. 3:122-126.

Fehr WR, Caviness CE (1977) Stages on soybean development. Ames: Iowa State University/Cooperative Extention Service (Special Report, 80).

França-neto JB, Pádua GP, Krzyzanowski FC, Carvalho MLM, Henning, AA, Lorini I (2012) Semente esverdeada de soja: causas e efeitos sobre o desempenho físiológico série sementes. EMBRAPA-CNPSO (Circular Técnica, 91). EMBRAPA-CNPSO, Londrina.

Griffin JL, Boudreaux JM, Miller DK (2010) Herbicides as harvest aids. Weed Sci. 58:355-358.

Guimarães VF, Hollmann MJ, Fioreze SL, Echer MM, Rodrigues-Costa ACP, Andreotti M (2012) Produtividade e qualidade de sementes de soja em função de estádios de dessecação e herbicidas. Planta Daninha. 30:567-573.

Hanway JJ, Thompson HE (1967) How a soybean plant develops. Ames: Iowa State University/Cooperative Extension Service (Special Report, 53). 
Instituto Adolfo Lutz - IAL (1985) Normas analíticas do Instituto Adolfo Lutz. 3rd edn. Instituto Adolfo Lutz, São Paulo.

Inoue MH, Marchiori Júnior O, Braccini AL, Oliveira Júnior RS, Ávila MR, Constantin J (2003) Rendimento de grãos e qualidade de sementes de soja após a aplicação de herbicidas dessecantes. Cienc Rural. 33:769-770.

Inoue MH, Pereira PSX, Mendes KF, Ben R, Dallacort R, Mainardi JT, Araújo DV, Conciani PA (2012) Determinação do estádio de dessecação em soja de hábito de crescimento indeterminado no Mato Grosso. Rev Bras Herbic. 11:71-83.

Kappes C, Carvalho MAC, Yamashita O M (2009) Potencial fisiológico de sementes de soja dessecadas com diquat e paraquat. Sci Agraria. 10:1-6.

Kappes C, Orsi JVN, Jesus Júnior AM, Carvalho MAC (2008) Efeitos dos dessecantes diquat e paraquat no potencial produtivo da cultura da soja. Cult Agron. 17:5767.

Krzyzanowski FC, França-Neto JB, Costa NP (1991) Efeito da classificação de sementes de soja por tamanho sobre sua qualidade e a precisão de semeadura. Rev Bras Sementes. 13:59-68.

Lacerda ALS, Lazarini E, Sá ME, Valerio Filho WV (2003) Armazenamento de sementes de soja dessecadas e avaliação da qualidade fisiológica, bioquímica e sanitária. Rev Bras Sementes. 25:97-105.

Lacerda ALS, Lazarini E, Sá ME, Valerio Filho WV (2001) Aplicação de dessecantes na cultura da soja: antecipação da colheita e produção de sementes. Planta Daninha. 19:381390.

Lamego FPI, Gallon MI, Basso CJI, Kulczynski SMI, Ruchel Q, Kaspary TEI, Santi A L (2013) Dessecação pré-colheita e efeitos sobre a produtividade e qualidade fisiológica de sementes de soja. Planta Daninha. 31:929-938.

Maguire JD (1962) Speed of germination-aid in selection and evaluation for seedling emergence and vigor. Crop Sci. 2:176-177.

Malaspina IC, Lazarini E, Oliveira WAS, Marcandalli LH, Fillanueva FCA (2012) Épocas de la aplicación de desecantes en el cultivo de la soja: tenor de agua y productividad. Rev Cienc Agron. 43:749-756.
Marcandalli LH, Lazarini E, Malaspina IC (2011) Épocas de aplicação de dessecantes na cultura da soja: qualidade fisiológica de sementes. Rev Bras Sementes. 33:241-250.

Marcos Filho J (2005) Fisiologia de sementes de plantas cultivadas. Editora Fealq, Piracicaba.

Marcos Filho J (1999) Teste de envelhecimento acelerado. In: Krzyzanowski FC, Vieira RD, França-Neto JB (eds) Vigor de sementes: conceitos e testes. Abrates, Londrina.

Moustaka J, Moustakas M (2014) Photoprotective mechanism of the non-target organism Arabidopsis thaliana to paraquat exposure. Pestic Biochem Phys. 111:1-6.

Nakagawa J (1999) Testes de vigor baseados no desempenho das plântulas. Comitê de Vigor de Sementes. Abrates, Londrina.

Rahman MM, Hampton JG, Hill MJ (2004) Soybean seed quality in response to time of desiccant application. Seed Sci Technol. 32:219-223.

Sediyama T, Teixeira RC, Barros HB (2009) Cultivares. In: Sediyama T (eds). Tecnologias de produção e usos da soja. Mecenas, Londrina.

Tecnologias de Produção de Soja - Região Central do Brasil 2012 e 2013 (2011) Embrapa Soja/Embrapa Cerrados/Embrapa Agropecuária Oeste. Embrapa Soja, Londrina.

Toledo MZ, Cavariani C, França-Neto JB (2012) Qualidade fisiológica de sementes de soja colhidas em duas épocas após dessecação com glyphosate. Rev bras Sementes. 34:134-142.

Toledo MR, Sediyama T, Barros HB (2009) Colheita, secagem e armazenamento. In: Sediyama $\mathrm{T}$ (eds) Tecnologias de produção e usos da soja. Editora Mecenas, Londrina. 